\title{
Working
}

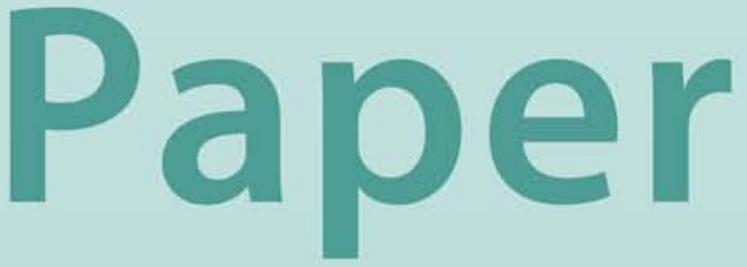


Is Housing Wealth an "ATM"?

The Relationship Between Household Wealth, Home Equity Withdrawal, and Saving Rates

Vladimir Klyuev and Paul Mills 
(C) 2006 International Monetary Fund

WP/06/162

\title{
IMF Working Paper
}

Western Hemisphere Department and International Capital Markets Department

\section{Is Housing Wealth an “ATM”? The Relationship Between Household Wealth, Home Equity Withdrawal, and Saving Rates}

\section{Prepared by Vladimir Klyuev and Paul Mills ${ }^{1}$}

Authorized for distribution by Tamim Bayoumi

June 2006

\begin{abstract}

\section{This Working Paper should not be reported as representing the views of the IMF.} The views expressed in this Working Paper are those of the author(s) and do not necessarily represent those of the IMF or IMF policy. Working Papers describe research in progress by the author(s) and are published to elicit comments and to further debate.

This paper examines the role increasing personal wealth and home equity withdrawal (HEW) have had in the decline in the personal saving rate in the United States. It does so by comparing the U.S. experience with those of Australia, Canada, and the United Kingdom. Mortgage market liberalization and innovation should reduce household cash flow and collateral constraints while making housing wealth more liquid as HEW becomes easier over time. Regression analysis indicates the expected negative relationship between U.S. saving and net worth, with a somewhat smaller coefficient than in previous studies. HEW is estimated to have a temporary negative impact on saving of the order of 20 cents on the dollar.
\end{abstract}

JEL Classification Numbers: E21, G21

Keywords: Household Saving, Home Equity Withdrawal, Housing Finance

Author(s) E-Mail Address: vklyuev@imf.org; pmills@imf.org

\footnotetext{
${ }^{1}$ The authors gratefully acknowledge comments and contributions by Tamim Bayoumi, Kornélia Krajnyák, Sam Ouliaris, and participants in the IMF seminar; help with data provided by the Reserve Bank of Australia and Statistics Canada; and excellent research assistance provided by Yoon Sook Kim, Andrew Swiston, and Volodymyr Tulin. All remaining errors are ours.
} 


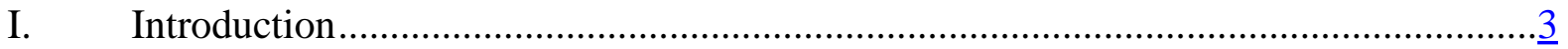

II. Have Saving Rates Really Fallen? ................................................................

III. Likely Impact of Financial Innovation and Liberalization on Home Equity Withdrawal (HEW) and Saving .............................................................

IV. Trends in HEW and Household Saving Across Countries .....................................11

V. How Does HEW Affect Household Saving? .........................................................13

VI. Econometric Analysis ...............................................................................

VII. Recent Experience of HEW in Australia and United Kingdom: Implications for United States? ................................................................................

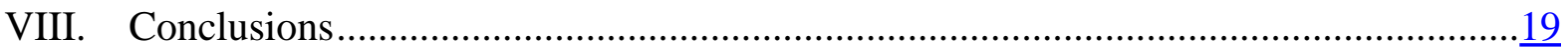

Appendices

I. Financial Liberalization and Mortgage Product Innovation ....................................21

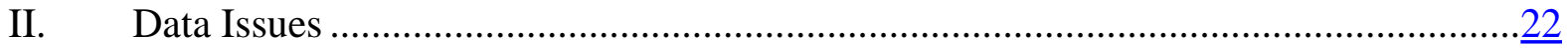

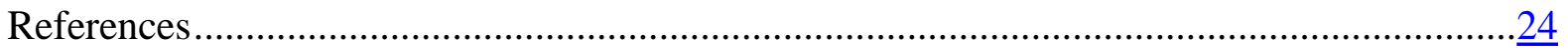

Box

1. Defining Home Equity Withdrawal ................................................................

Tables

1. United States: Time-Series Regression Results for Household Saving......................16

2. Canada: Time-Series Regression Results for Household Saving .............................17

3. Australia: Time-Series Regression Results for Household Saving...........................17

4. United Kingdom: Time-Series Regression Results for Household Saving ................17

5. Panel Regression Results for Household Saving ................................................18

Figures

1. Household Saving Rates: National Definitions ......................................................

2. United States: Household Saving Rate Adjusted for Effects of Inflation on FixedIncome Assets and Liabilities ........................................................................ $\underline{5}$

3. United States: Household Saving Rate Adjusted for Treatment of Rental Expenditure and Residential Capital Consumption........................................................... $\underline{5}$

4. $\quad$ Adjusted Household Saving Rates ...........................................................................

5. Mortgage-Backed Securities as a Share of Mortgages Outstanding.............................

6. Ratio of Unsecured Credit to Total Household Debt ............................................10

7. Uses of Net Saving...................................................................................... 12

8. House Price Increases and Consumption Growth..................................................19

9. Australia and United Kingdom: House Prices and Home Equity Withdrawal ............. 19 


\section{INTRODUCTION}

“It's like installing an ATM on the side of your house.” Loan advertisers and financial commentators have been quick to identify the rise in additional secured borrowing in the United States with withdrawing housing equity to finance consumption. The former laud the flexibility of borrowing against housing collateral to consume; the latter fret that U.S. households are overstretching by adding to their debt burdens and eroding the equity in their houses. The decline in the U.S. personal saving rate, such that households are now consuming more than their disposable incomes, is readily ascribed to the rise of home equity withdrawal (HEW).

This paper assesses whether reality matches this perception. First, does the negative U.S. household saving rate (hereafter referred to simply as saving) reflect reality or is it a statistical artifact? Second, what role, if any, has financial liberalization played in reducing U.S. saving and fostering HEW? Third, to what degree have increasing housing wealth and HEW been responsible for the decline in U.S. saving?

The paper addresses these questions, comparing the U.S. experience with those of Australia, Canada, and the United Kingdom to see if other countries with competitive mortgage markets and similar home-ownership rates provide additional insight into the interaction of housing wealth and savings. It does so by first describing financial sector innovation in each country, which helps to calibrate the degree to which constraints on accessing home equity have been relaxed. The paper then uses regression analysis to draw possible implications for the U.S. personal saving rate of the slowing housing market.

\section{Have Saving Rates Really Fallen?}

The household saving rate-the ratio of household net saving to personal disposable income-has been on a declining trend in the United States since the mid-1980s, and finally turned negative in 2005. Over the last decade, saving rates have also declined in other large, industrial economies with "Anglo-Saxon" financial markets, notably Australia, Canada, and United Kingdom (Figure 1). ${ }^{2}$

Recent declines in saving rates, and particularly their fall into negative territory, have given rise to concerns about measurement issues. Some of these are conceptual, questioning whether the measure employed in the national accounts is appropriate; others are more technical,

\footnotetext{
2 The household saving rate has declined substantially in New Zealand as well.
} 
asking whether changes in the behavior of certain macroeconomic variables may have affected the measured saving rate without genuine changes in household behavior.

The main conceptual issue is whether saving should be calculated as the difference between disposable income and consumption (a flow measure) or as a change in the household net wealth (a stock measure). This is a long-standing issue (see, for example, Hicks, 1939). The main argument of statistical agencies (Perozek and Reinsdorf, 2002), which report the flow measure in national accounts, is that it is appropriate for measuring funds available to finance new investment, while valuation changes, which account for the difference between the stock and the flow measures, do not create "real wealth."

Although generally applicable, this argument does not hold in some instances. For example, if dividends paid by firms to households are banked and then on-lent to firms to expand capacity, household wealth and saving will increase by the amount of the dividend. If firms invest out of retained earnings rather than paying dividends, however, household wealth still increases as stock prices rise, reflecting the value of the investment, but measured saving rises in the corporate, rather than household, sector. As another example, an increase in net financial claims on foreigners owing to valuation changes may be considered accumulation of real wealth for residents.

One might also assert that flows largely reflect underlying household decisions, while changes in stocks are affected by volatile movements in market prices. This could reduce the stock measures' usefulness as an indicator of underlying trends in the economy. In addition, given the volatility of asset prices, the marginal propensity to consume out of income is much larger than that out of wealth, since households treat unrealized capital gains as potentially transient. A final aspect of capital gains is that they have to be realized to provide funds available to fund expenditure, although as a consequence of financial market development, including home equity withdrawal, this is less of an issue.

We do not take a position in this debate, since the purpose of the paper is to explain movements in the measured flow saving rate. We note, however, that the household saving rate as defined by national accounts may well decline in periods of rapid asset price appreciation without driving down the ratio of household net worth to disposable income.

Another well-recognized conceptual issue has to do with the erosion of the real value of fixed nominal assets owing to inflation (Jump, 1980). As inflation goes up, the interest rate also increases, pushing up both disposable income and saving by the same amount, assuming there is no change in real consumption. The result is that one tends to observe higher saving rates in periods of high inflation. The correlation, however, is spurious, ${ }^{3}$ as the inflation

\footnotetext{
${ }^{3}$ The link considered here is purely mechanical. There may be a behavioral change if households raise precautionary saving, since higher inflation typically means more uncertainty.
} 
component of higher interest receipts represents not return on investment but rather return of investment, that is compensation for the erosion in the real value of financial assets. ${ }^{4}$

A simple adjustment subtracts the product of the inflation rate and the stock of fixed-income assets from disposable income and from net saving and adds the product of the inflation rate and the stock of liabilities to net saving. As Figure 2 demonstrates, this adjustment indeed lowers the U.S. saving rate perceptibly in the high-inflation period of the 1970s-1980s. The adjustment changes sign at the end of the 1990s, as the stock of household fixed-income assets falls below that of liabilities. At the same time, the adjustment is clearly insufficient to account for more than a small fraction of the decline in the saving rate. This conclusion pertains to the other three countries as well.

There are also technical concerns related to asset price inflation. First, although realized capital gains are not included in household income, taxes on them are deducted, driving down disposable income and the saving rate. According to Reinsdorf (2004), capital gains taxes equaled 1.65 percent of U.S. household disposable income in 2000, at the peak of realized holding gains, and their increase contributed 0.5 percentage point to a 5.9 percent decline in the saving rate between 1992 and 2001. The importance of capital gains taxes declined after the bursting of the dot-com bubble, and so has the wedge between the standard measure of household

Figure 2. United States: Household Saving Rate Adjusted for Effects of Inflation on Fixed-Income Assets and Liabilities

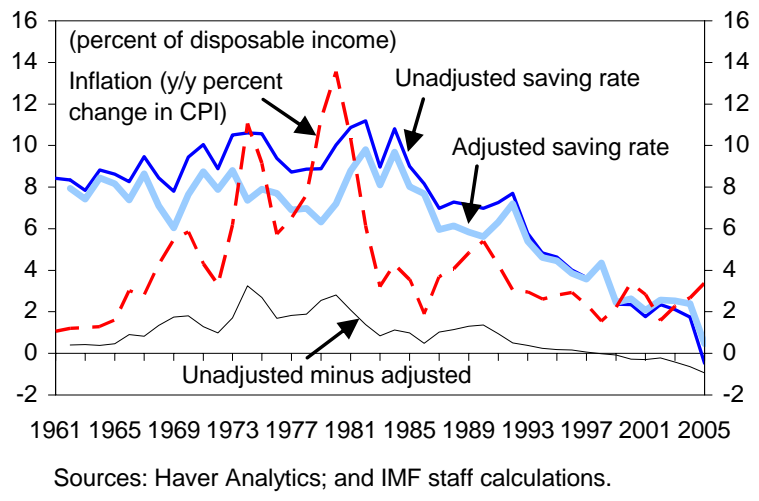

Figure 3. United States: Household Saving Rate Adjusted for Treatment of Rental Expenditure and Residential Capital Consumption

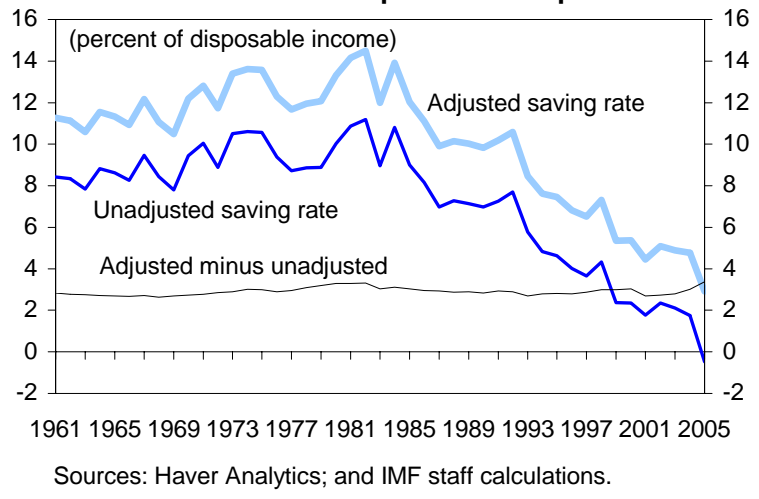
saving and the one that does not subtract capital gains taxes. ${ }^{5}$

Second, an increase in house prices drives up imputed rents and consumption of fixed capital, lowering the saving rate even if there is no change in household behavior. A simple way to

\footnotetext{
${ }^{4}$ Looking at a ratio of real household saving to real disposable income would not solve the problem, since both saving and income would be deflated using the same price index, and the ratio would not be affected. The issue is that consumption expenditure and non-asset income are proportional to the price level, while the inflationary component of interest receipts and payments is proportional to the rate of price increases.

${ }^{5}$ The reduction in realized capital gains may explain some of the sideways drift in the household saving rate early in this decade before the plunge in 2004-2005.
} 
judge the importance of this effect is to examine the evolution of the ratio of gross saving to the difference between gross disposable income and imputed rent. Figure 3 shows that such an adjustment raises the U.S. household saving rate by a remarkably stable amount, so the previously mentioned factors do not help explain the evolution of the measured saving rate over time.

Other corrections considered in the literature, such as splitting personal income and saving into those of households and nonprofit institutions serving households or excluding definedbenefit pension plans from the personal sector, also have little impact on the measured fall in saving (Reinsdorf, 2004). Thus, we conclude that although a number of factors may have magnified the decline in the flow measure of the saving rate, the bulk of the decline is real. Saving ratios for the four countries in our sample, adjusted for consumer price index (CPI) and house price inflation, are shown in Figure 4.

Figure 4. Adjusted Household Saving Rates 1/
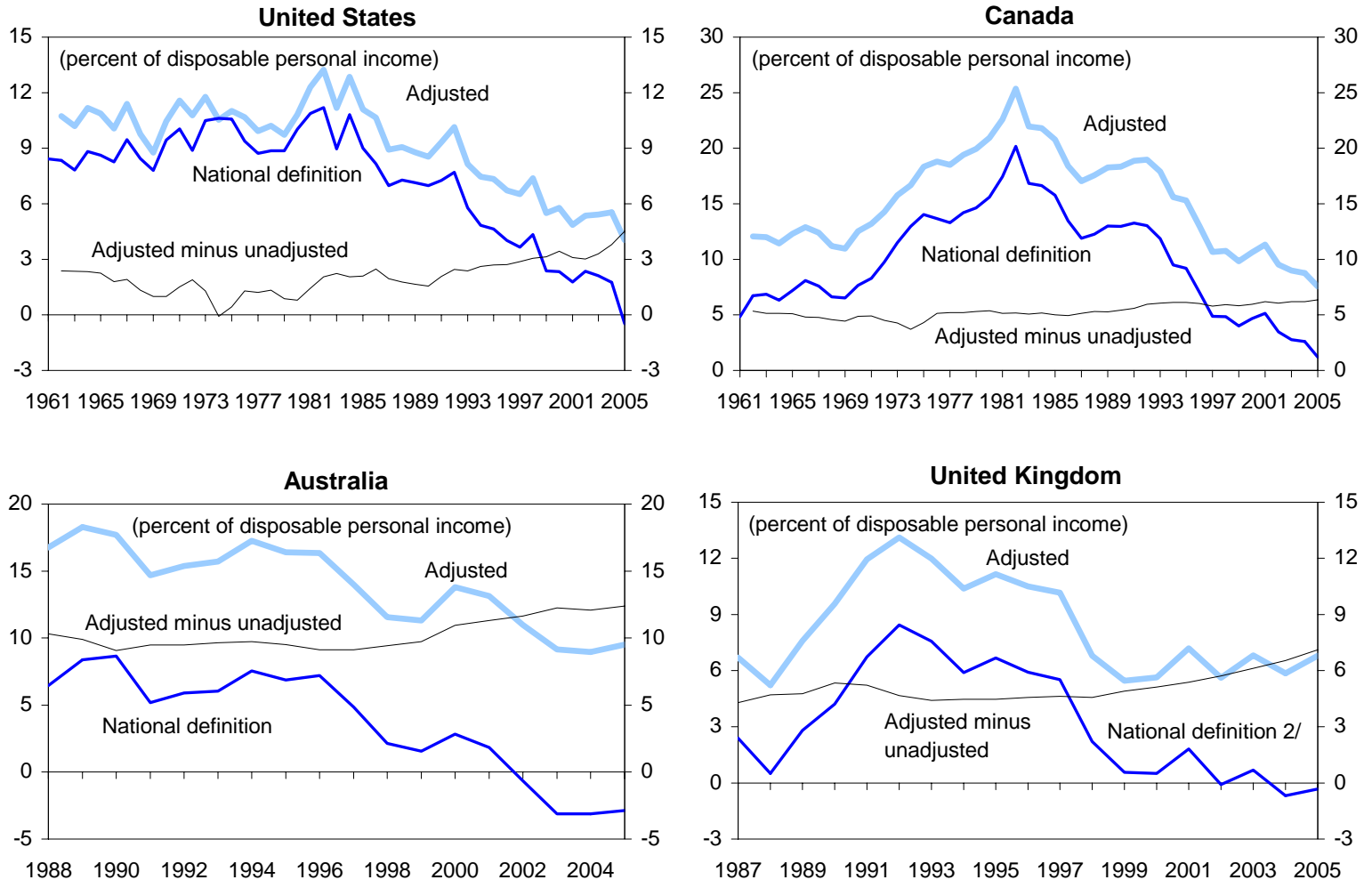

Sources: Haver Analytics; National Sources; and IMF staff calculations. $1 /$ See the text for a description of the adjustments.

2/ Excludes residential capital consumption allowance from income and saving, as is the case for the other countries. 


\section{LIKELY IMPACT OF FINANCIAL INNOVATION AND LiBERALIZATION ON HOME EQUITY WITHDRAWAL (HEW) AND SAVING}

Saving behavior, especially 'buffer-stock' saving, will be affected by the ease with which households can borrow to finance consumption or durable and house purchases. Financial liberalization and innovation in the provision of borrowing facilities to households eased these constraints in the four countries under consideration (see Appendix I). Initially, measures concentrated on relaxing controls on the ability of financial institutions to attract deposits or to satisfy the potential demand for credit. Liberalization of deposit and lending markets permits intermediaries to raise finance more cheaply and satisfy loan demand if their expected rate of return on capital justifies the extension of their balance sheets and commitment of scarce capital.

Also, a reduction in mortgage and refinancing transaction costs can be achieved by increasing competition in loan markets (through new entrants, foreign competitors, and new technology). Competition can be facilitated by the entry of purely wholesale-financed lenders unconstrained by the sunk costs required to attract retail deposits, and by mortgage brokers originating mortgages to be securitized in pools of loans backing mortgage-backed securities. The ability of lenders to securitize mortgages (and other consumer loans) allows access to a wider range of investor capital, increases the ability of lenders to manage their capital and so potentially reduces the cost of mortgages. ${ }^{6}$

One indication of the competitiveness and potential for innovation on the mortgage market is the degree to which the stock of mortgages has been securitized. As illustrated by Figure 5, U.S. mortgage securitization expanded rapidly in the 1980s and 1990s so that mortgage-backed securities (MBS) now finance around 60 percent of the U.S. mortgage stock. Elsewhere, MBS markets have only grown rapidly in the last decade. The Australian market increased

Figure 5. Mortgage-Backed Securities as a Share of Mortgages Outstanding

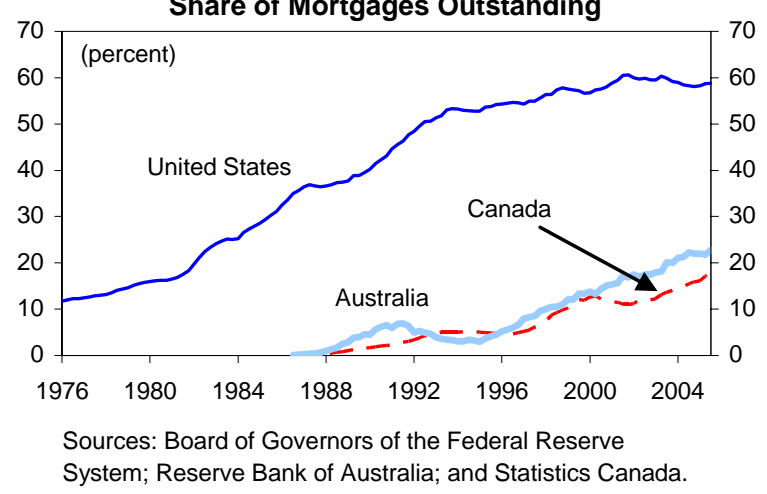
from around 3 percent of mortgages outstanding in the mid-1990s to around 22 percent in 2006 while that in Canada grew from 4 percent to around 16 percent in the same period. While no time series is available to show the trend, MBSs were first issued in the United Kingdom in the late 1980s and accounted for 12 percent of the mortgage stock by the end of 2004 (CML, 2005, p.6), a similar ratio to that of Canada.

\footnotetext{
${ }^{6}$ A possible adverse effect of securitization is to increase credit rationing for those borrowers whose characteristics do not meet the criteria needed for eligibility into the pools of mortgages to be securitized.
} 
In addition, advances in credit scoring techniques (through the greater availability of data on pools of borrowers) have reduced default risk premia while search costs have fallen through the development of the internet and competition amongst mortgage brokers. ${ }^{7}$ These developments have helped to ensure that access to credit is extended to borrowers of more marginal creditworthiness.

Financial innovation, competition, and technological advance should therefore have a number of effects on the housing market. First, liberalization increases the access of marginally creditworthy borrowers to loans and reduces the need for first-time buyers to save for substantial down payments. ${ }^{8}$ Second, transaction and search costs are lowered for taking out a mortgage, refinancing it and moving house. Third, borrowing against existing collateral (e.g., through home equity loans or second mortgages) should be cheaper and available to more households, thus increasing the accessibility of accumulated housing equity. As credit rationing constraints are relaxed, increasing the supply of credit for any given interest rate, it is likely that both consumption and house prices will rise simultaneously. Hence, financial liberalization and innovation can itself help drive the saving ratio down.

Such financial innovation should also allow greater flexibility for households to smooth consumption through time when income is expected to grow; enable households to borrow to maintain consumption when income is subject to shocks; and increase the liquidity of housing wealth relative to financial assets. Hence, one would expect mortgage innovation to lead to a higher and less volatile average propensity to consume from income, and an increase in the value of housing as an investment asset as its liquidity increases. ${ }^{9}$ By relaxing immediate cash flow constraints and providing greater flexibility over the interest paid in the immediate future, such changes may also soften the immediacy of the elasticity of consumption with regard to changes in nominal interest rates. Part of this smoothing will occur through HEW.

\footnotetext{
${ }^{7}$ See Frankel (2006) for a discussion of how the credit scores of mortgages backing non-agency MBS have declined markedly between 2000 and 2005.

${ }^{8}$ Frankel (2006) shows how the share of 'prime' mortgages backing U.S. non-agency MBS issuance has fallen from around 50 to 25 percent since 1995 as 'Alt-A' and subprime lending has grown. Subprime loans now constitute 9 percent of U.S. securitized mortgage debt and financed 15 percent of home sales in 2005 (JP Morgan, 2006, p.29).

${ }^{9}$ Boone, Girouard, and Wanner (2001) find that financial deregulation and innovation raised the marginal propensity to consume in Canada, the United Kingdom and the United States (Australia was not included in the sample). Borrowers may also seek to reduce interest costs by refinancing unsecured consumer credit through cheaper secured debt, especially if interest on mortgage debt is tax advantaged relative to unsecured debt (as it has been in the U.S. since the Tax Reform Act of 1986).
} 


\section{Box 1. Defining Home Equity Withdrawal}

Home equity withdrawal (HEW) is the generic description for transactions whereby homeowners collectively reduce the equity in their homes. HEW can arise as the result of housing transactions, additional borrowing, or a combination of the two. HEW rises when homeowners:

- $\quad$ Take out a mortgage with a value in excess of that of the house;

- $\quad$ Exercise negative amortization options, thereby increasing their debt;

- $\quad$ Remortgage or refinance their existing mortgage with a higher principal;

- $\quad$ Take out a second mortgage or home equity loan;

- $\quad$ Increase their mortgage indebtedness when moving into a new house of similar value;

- $\quad$ Trade down to a lower-value house when they have no mortgage or while maintaining their level of secured debt;

- $\quad$ Sell a house, repaying any mortgage, to move into rental accommodation or realize a bequest.

Conversely, households inject equity into their holdings of housing wealth when they:

- $\quad$ Make a down payment on a first-time purchase;

- $\quad$ Make amortization and additional payments on a mortgage or home equity loan;

- $\quad$ Remortgage, or refinance their existing mortgage, with a lower principal;

- $\quad$ Reduce their mortgage indebtedness when moving into a house of similar value;

- $\quad$ Purchase second homes and investment properties with cash;

- $\quad$ Finance home improvements other than through a mortgage.

Net HEW is the difference between these two measures. When home improvements are financed through secured borrowing, there should be no impact on net HEW.

As can be envisaged from the components of HEW (see Box 1), it is often strongly linked with the level of housing transactions and increasing housing equity due to price appreciation. Indeed, a substantial component of gross HEW has been extracted as a result of housing turnover in the United States since the mid-1990s (Greenspan and Kennedy, 2005). However, HEW has been also been found to be strongly positively correlated with the degree of mortgage market completeness (Catte and others, 2004). ${ }^{10}$ Financial liberalization and innovation makes HEW easier by:

\footnotetext{
${ }^{10}$ This study examined the degree to which HEW as a proportion of disposable income was related to a constructed indicator of mortgage market completeness in eight European Union countries from 1990 to 2002.
} 
- $\quad$ Reducing the delay and transactions costs of refinancing. Innovation in credit scoring and greater competition has resulted in a sharp fall in the transactions costs of refinancing. ${ }^{11}$ As a result, households are more likely to refinance their fixed rate loans when interest rates fall and when they wish to withdraw equity. Krainer and Marquis (2003) attribute the far higher rate of U.S. mortgage refinancing in 2001-02 compared to 1990-91, despite a similar decline in long-term mortgage rates, to the greater build-up of home equity and lower transactions costs. Lower transactions costs also increase the 'churn' rate on house purchases, providing opportunities to extract equity. The average life of a mortgage in the United Kingdom fell from seven years in 1995 to three in 2004.

- $\quad$ Introducing flexible mortgage terms. A number of new mortgage products include cheap or costless options to borrow against existing equity in one's home. For instance, in Australia and the United Kingdom, “offset” mortgages, in which transaction balances are netted off from the borrower's mortgage debt, provide flexibility for the debt to rise as long as a degree of equity is maintained in the house. Similarly, a significant proportion of U.S. mortgages extended in 2004-2005 contain negative amortization options, so permitting the borrower to increase debt flexibly against their equity.

- $\quad$ Increasing access to second mortgages and home equity loans. Better credit scoring and mortgage broker competition have increased access to, and lowered the relative rate charged on, secondary mortgages. In the United States, this trend has also been driven by the dramatic growth in the issuance of securitized pools of home equity loans (HELs) and lines of credit (HELOCs), thus reducing their cost. ${ }^{12}$ Since the early 1970 s, when unsecured debt accounted for a third of U.S. household borrowing, there has been a trend decline in the share of unsecured to total household debt (see Figure 6), encouraged by the withdrawal of the tax deductibility of interest on unsecured debt in 1986.

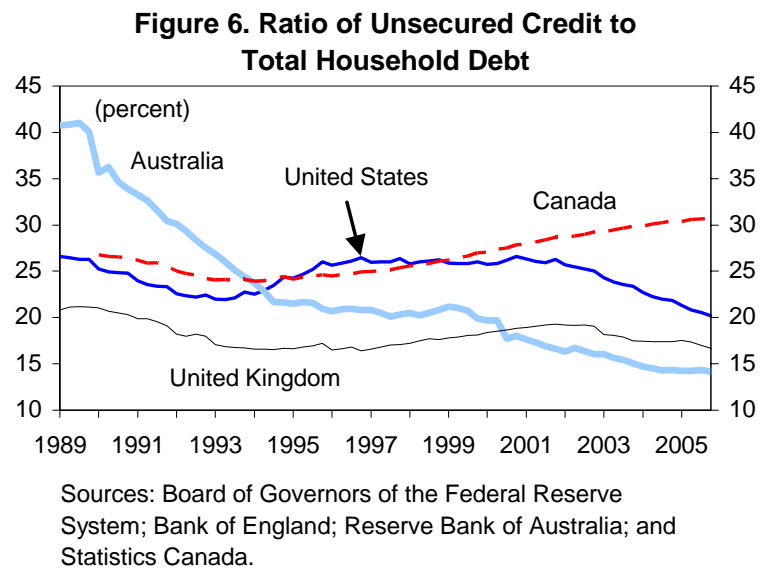

\footnotetext{
${ }^{11}$ In the United States, according to Freddie Mac data, as a proportion of the loan, average fees and points charged on a 30-year fixed rate mortgage have fallen from 2.5 percent in 1984 to 0.6 percent in 2005. Consequently, long-term interest rates need to fall significantly less than previously to make it worthwhile for the borrower to refinance in net present value terms (Bennett, Peach, and Persistani, 2001).

${ }^{12}$ Issuance of U.S. HEL and HELOC asset-backed securities rose from \$61 billion in 1999 to \$515 billion in 2005 (JP Morgan, 2006).
} 
This movement has been most pronounced in Australia but has only recently begun to reassert itself in the United Kingdom and United States following a cyclical upswing. Canada displays a contrary tendency, with unsecured consumer borrowing growing strongly relative to mortgage debt due to the absence of cost-effective HEL products.

- Increasing ability to access home equity in retirement. Although not significant in absolute amounts in any of the four countries, home equity release loans, designed for older homeowners to generate income in retirement, are beginning to become more widely available and publicized. ${ }^{13}$ Such products enable housing equity to be converted into income without the need to move home in retirement. Their existence reinforces the belief that home equity can be used as a supplement to pension savings.

\section{Trends In HEWAND Household SAVIng ACross Countries}

One way to examine the link between HEW and saving is in the context of an accounting relationship between national accounts and flow-of-funds accounts. In principle, net saving should equal the increase in net assets, real or financial, although in practice the two are somewhat different since they are estimated from different sources. ${ }^{14}$ Figure 7 shows the decomposition of household net saving into net home equity injection (the difference between net investment in housing and net borrowing secured on housing, that is HEW with the sign reversed) and net flow into financial assets (net acquisition of financial assets minus net nonsecured borrowing). One can observe substantial differences across countries.

In the United States, from 1961 until the mid-1990s, HEW was fairly small relative to household income and switched from negative to positive and back, moving, if anything, in the same direction as the saving rate. It is only in the last ten years that a pronounced growth in the HEW ratio has coincided with a decline in household saving. At the same time, flows into net financial assets tended to rise, at least after the collapse of the IT bubble, giving credence to the claim that HEW was largely used for portfolio rebalancing (paying off more costly nonsecured debt and moving wealth from residential to financial assets).

\footnotetext{
${ }^{13}$ Such schemes generally take one of two forms. A home reversion plan entails a homeowner selling all or part of their home for a lump sum with the right to remain in occupation. On sale, the lender receives their equity share of the proceeds. A lifetime mortgage involves the borrower remortgaging their house to take a cash lump sum or annuitised income stream. Interest accumulates and is settled on the sale of the property. In the United Kingdom, roughly $£ 11 \frac{1}{4}$ billion p.a. of home reversion mortgages and home income plans were sold in 20032005 (FSA, 2006).

${ }^{14}$ This analysis uses comparable definitions across countries, hence it does not necessarily reproduce national data.
} 
Figure 7. Uses of Net Saving

\section{United States}
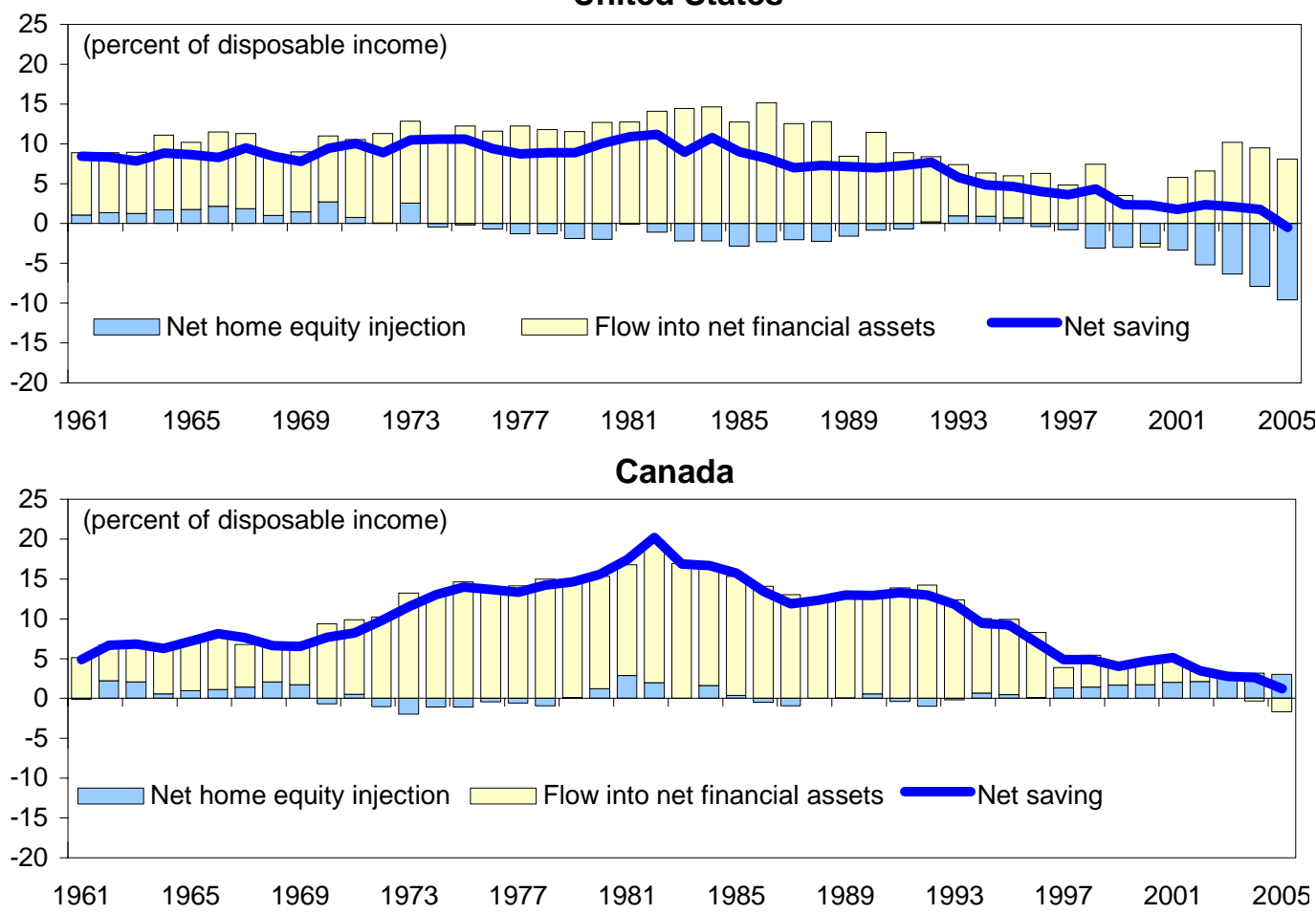

Australia
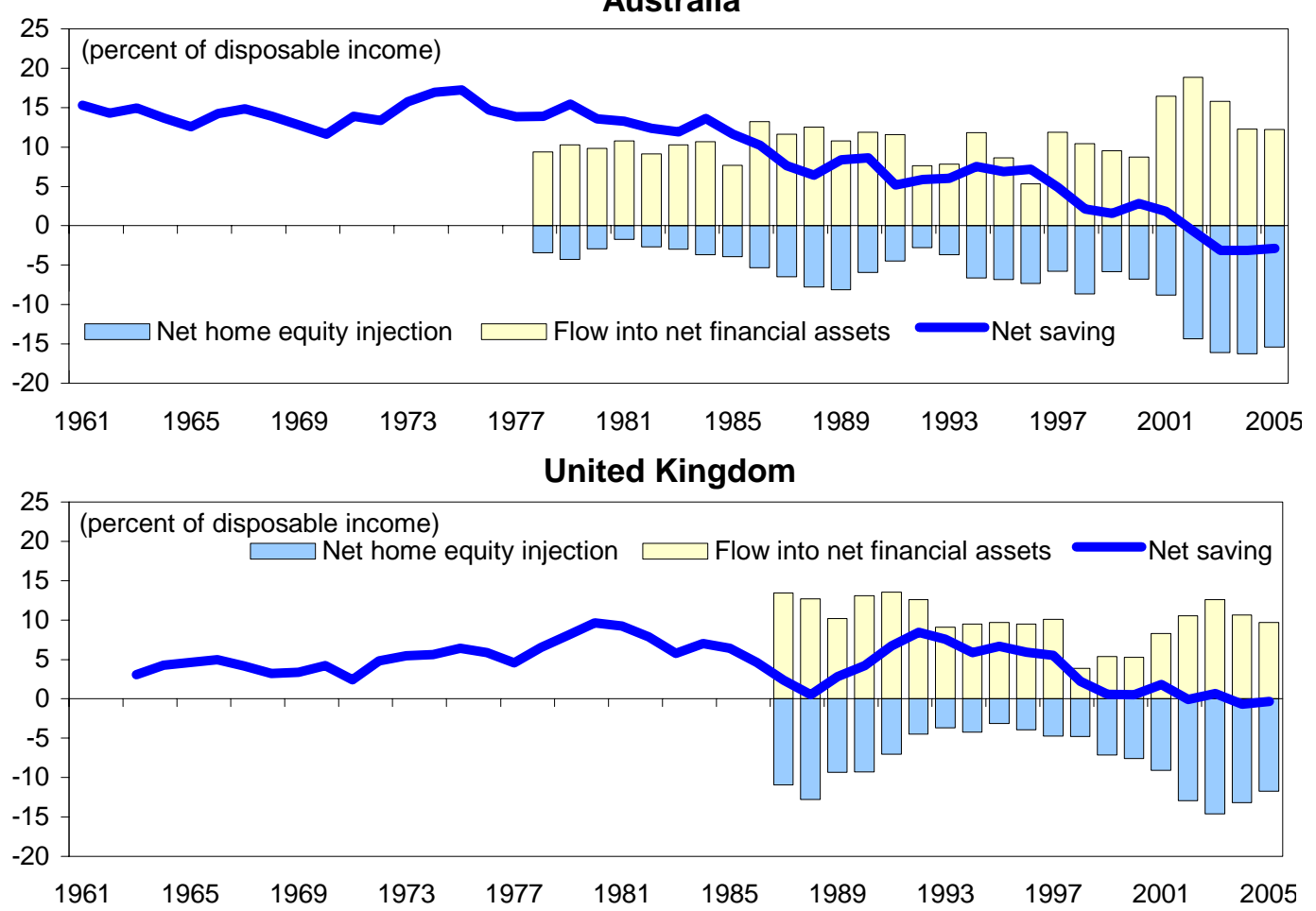

Sources: Haver Analytics; National Authorities; IMF Fund staff calculations. 
Canada is unique among the four countries in that is has not witnessed substantial home equity withdrawal. Moreover, in the last few years home equity injection has picked up noticeably, in a development possibly related to a housing boom in western Canada. Rather, the decline in household saving has reflected diminishing flows into financial assets.

Both Australia and the United Kingdom featured substantial home equity withdrawal in the short periods for which data are available. In Australia, HEW has increased while the saving rate has declined since the late 1970s, although fluctuations of the two variables have not been synchronous. In the United Kingdom, HEW and the saving rate have generally moved in opposite directions since the late 1980s. Both countries have recently experienced a sharp reduction in house price appreciation, which was associated with some decline in home equity withdrawal and stabilization of the saving rate. Flows into net financial assets have not exhibited an apparent trend in either country.

\section{How Does HEW AfFect Household Saving?}

Two schools of thought have emerged that differ in the influence on consumption they ascribe to HEW. One believes that the strong negative correlation of HEW with saving rates (particularly in the United States since the mid-1990s) indicates causation and that HEW has a strong influence in driving consumption growth. This school expects there to be a strong impact on consumption if the U.S. housing market slows and HEW declines sharply. The other school regards any such correlation as being largely driven by independent factors that lead to rising HEW and falling saving (e.g., rising income expectations or a positive house price shock). According to this line of argument, while undoubtedly some proceeds from HEW find their way into immediate consumption, the direct impact is not likely to be substantial. Any increase in U.S. saving as a result of a cooling housing market will arise from households' reaction to lower wealth rather than lower HEW.

Previous literature provides mixed messages. In two cross-country OECD studies (Boone, Girouard, and Wanner, 2001; Catte and others, 2004), HEW is found to be strongly positively associated with a high estimated marginal propensity to consume from housing wealth. Indeed, Catte and others (2004) find that HEW dominates housing wealth as a driver of consumption, with 89 percent of HEW estimated to be consumed in the United Kingdom, 63 percent in Canada and Australia, and 20 percent in the United States.

Conversely, survey evidence from homeowners about their motives for extracting home equity indicates that limited proportion is used to finance immediate consumption, although it may boost residential investment through home improvements. A 2004 survey of Australian homeowners found that the bulk (72 percent) of HEW was extracted via property transactions, principally through older owners selling to younger buyers with larger mortgages. Two-thirds of HEW was used to acquire financial assets or pay off debts with household expenditure accounting for 18 percent (RBA, 2005). A similar picture is painted by a U.K. survey of households conducted in 2003. The majority of HEW arises from 
housing transactions with the most commonly cited motive being to save or pay off other debts. Expenditure was, however, a significant reason for many of those withdrawing equity through second mortgages or refinancing, primarily for the purpose of home improvement (Benito and Power, 2004). ${ }^{15}$

U.S. survey evidence for the uses of some types of HEW comes from questions posed to householders concerning the use of funds released from cash-out refinancing (Canner, Dynan, and Passmore, 2002). Within the survey period (2001-2002H1), 45 percent of those who refinanced their mortgage extracted equity, amounting to an estimated $\$ 132$ billion. Of this HEW, 35 percent was used on home improvements, 26 percent for the repayment of debt, 21 percent for the acquisition of real assets, and 16 percent to finance consumers' expenditure.

Although the format of these surveys differs across countries, a similar picture emerges. This is one of HEW primarily occurring to the greatest extent through housing transactions rather than homeowners increasing their mortgage debt with households using the equity extracted primarily to acquire financial assets or repay other debts. Spending intentions were focused principally on home improvements (leading to no net effect on HEW) with usually less than 20 percent used to finance consumption. Hence, although some HEW is consumed, it appears to be used primarily as a tool for acquiring financial assets, repaying more expensive debts, or improving the housing stock.

\section{ECONOMETRIC ANALysis}

This section uses an econometric model to explore the reasons for the decline in the household saving rate and the role HEW might play, focusing on four explanatory variables: net worth as a ratio of personal income, the short-term real interest rate, inflation, and HEW as a proportion of personal income. As indicated above, rapid asset price appreciation may leave household wealth unchanged or even rising relative to income, even as the saving rate goes down. In a life-cycle model, such as that by Galí (1990), an increase in wealth relative to income would induce households to increase their consumption relative to income, financing it out of wealth, and thus bring down the saving rate. The effect of an increase in the real interest rate on saving theoretically is ambiguous, as the higher reward for saving may be offset by an income effect if net financial assets are positive, but most empirical studies have found the substitution effect to dominate. Higher inflation is expected to be associated with higher saving, both owing to the need for the households to compensate for the erosion in the real value of their assets, as discussed above, and, possibly, due to precautionary saving in the face of heightened uncertainty. Also, the saving rate may exhibit

\footnotetext{
${ }^{15}$ In addition, the Dutch National Bank surveys households in the Netherlands annually to assess their use of HEW (van Els, van den End, and van Rooi , 2005). In 2003, respondents said that increases in secured debt were predominantly (70 percent) used for home improvement, followed by savings and investments (10 percent), consumption ( 8 percent), and repayment of other debt (6 percent).
} 
a downward trend, reflecting financial market development, which relaxes liquidity constraints and reduces the need for precautionary saving, and, possibly, demographic developments. Finally, we explore the degree to which the HEW ratio affects the household saving ratio in the short and long run. Our prior is that it is likely to matter in the short run, but less so over time as alternative forms of wealth become more fungible.

We model the evolution of the saving rate in an error-correction framework, where in the long run the saving rate is cointegrated with the net worth ratio and, potentially, real interest rate and inflation. In the short run, the saving rate changes in response to its deviation from the long-run equilibrium (the error-correction term) and, potentially, other variables. As we are interested in the impact of home equity withdrawal on the saving rate, we will include it, as a percentage of household disposable income, both in the long-run and in the short-run relationships.

Our general specification takes the form:

$$
\Delta s_{t}=\alpha+\alpha_{h} \Delta h e w_{t}-\gamma\left(s_{t-1}-\beta_{n} n w_{t-1}-\beta_{r} r_{t-1}-\beta_{\pi} \pi_{t-1}-\beta_{t} t-\beta_{h} h e w_{t-1}\right)+\varepsilon_{t},
$$

where $s$ is household saving, hew is home equity withdrawal, $n w$ is household net worth (financial and residential assets net of liabilities), all measured as a ratio to disposable income), $r$ is the short-term real interest rate, $\pi$ is CPI inflation, and $t$ stands for the time trend. ${ }^{16}$ Statistical tests indicate that these variables have a unit root in level, but are stationary in first differences, and that they are bound by a cointegrating relationship. Changes in cyclical variables, such as real GDP and the unemployment rate, were initially added to the dynamic equation but were consistently not significant. Annual data were used, with the estimation period being dictated by the availability of housing wealth data.

As can be seen from Table 1, in the long run the U.S. personal saving rate tends to decline when household net worth rises relative to disposable income, ${ }^{17}$ with a coefficient slightly greater than two cents on the dollar, ${ }^{18}$ and rises with increases in the real interest rate and inflation. In addition, for given values of the explanatory variables, the saving rate trends down over time, probably indicating a reduction in precautionary saving as liquidity constraints were relaxed due to gradual financial liberalization. Home equity withdrawal was not found statistically significant in the long-run relationship, so equation (1) was reestimated without that term. A ten percentage point increase in the ratio of HEW to disposable income is associated with a temporary $1 \frac{1}{2}-2$ percentage point decline in the saving rate, although the coefficient was different from zero at only the 12 percent

\footnotetext{
${ }^{16}$ See Appendix II for variable definitions and data sources.

${ }^{17}$ When entered separately, net housing wealth (value of real estate net of debt secured on dwelling) and net financial wealth (financial assets net of nonsecured debt) had similar quantitative impact on saving.

${ }^{18}$ This coefficient is somewhat smaller than values reported in other studies (e.g., Maki and Palumbo, 2001).
} 
probability level. An increase in household net worth explains 13/4 percentage points of a 6 percentage point decline in the personal saving rate since 1993, while the contribution of an increase in HEW is about $1 / 4$ percentage points. At the same time, an increase in HEW also explains $1 / 4$ percentage points of a $23 / 4$ percentage point decline in the saving rate between 2000 and 2005, when household net worth ratio did not change from the beginning to the end of the period.

Table 1. United States: Time-Series Regression Results for Household Saving 1/

\begin{tabular}{|c|c|c|c|c|c|c|}
\hline & \multicolumn{3}{|c|}{ HEW in Long and Short Run } & \multicolumn{3}{|c|}{ HEW in Short Run Only } \\
\hline & Coefficient & Standard error & & Coefficient & Standard error & \\
\hline \multicolumn{7}{|l|}{ Long-run relationship } \\
\hline Net worth & -0.02 & $(0.004)$ & $* * *$ & -0.02 & $(0.005)$ & $* * *$ \\
\hline Real interest rate & 0.38 & $(0.08)$ & $* * *$ & 0.39 & $(0.08)$ & $* * *$ \\
\hline Inflation rate & 0.39 & $(0.07)$ & $* * *$ & 0.39 & $(0.07)$ & $* * *$ \\
\hline Trend & -0.13 & $(0.02)$ & $* * *$ & -0.14 & $(0.01)$ & $* * *$ \\
\hline HEW & -0.11 & $(0.09)$ & & & & \\
\hline Error-correction term & 0.85 & $(0.16)$ & $* * *$ & 0.83 & $(0.16)$ & $* * *$ \\
\hline$\Delta(\mathrm{HEW})$ & -0.18 & $(0.11)$ & & -0.16 & $(0.11)$ & \\
\hline
\end{tabular}

Source: IMF staff calculations.

1 / Dependent variable is the difference in the saving rate. The estimation uses annual data for the 1963-2005 period. Standard errors are in parentheses. *,**, and *** indicate significance at the 10 percent, 5 percent, and 1 percent levels, respectively.

Results for the other countries (reported in Tables 2-4) confirm a negative relationship between the saving rate and household net worth, with coefficients of the same order as in the United States. ${ }^{19}$ Real interest rate and inflation were positively correlated with the saving rate in Canada, but in the relatively short time series for Australia and the United Kingdom the relationship was not found statistically significant. The coefficient on the time trend was not found to be significant in any of these countries, which is perhaps not surprising given the short samples for Australia and the United Kingdom, and the limited evidence of financial innovation in Canada.

\footnotetext{
${ }^{19}$ The coefficient was not statistically significant in U.K. regressions.
} 
Table 2. Canada: Time-Series Regression Results for Household Saving 1/

\begin{tabular}{lccccccc}
\hline & \multicolumn{2}{c}{ HEW in Long and Short Run } & & \multicolumn{3}{c}{ HEW in Short Run Only } \\
\cline { 3 - 4 } & Coefficient & Standard error & & Coefficient & Standard error & \\
\hline Long-run relationship & & & & & & & \\
Net worth & -0.03 & $(0.02)$ & $*$ & & -0.06 & $(0.02)$ & $* * *$ \\
Real interest rate & 0.78 & $(0.18)$ & $* * *$ & 0.67 & $(0.25)$ & $* *$ \\
Inflation rate & 1.21 & $(0.21)$ & $* * *$ & & 1.15 & $(0.28)$ & $* * *$ \\
HEW & 1.02 & $(0.46)$ & $* *$ & & & & \\
Error-correction term & 0.40 & $(0.10)$ & $* * *$ & & 0.30 & $(0.09)$ & $* * *$ \\
$\Delta$ (HEW) & -0.03 & $(0.22)$ & & -0.21 & $(0.21)$ & \\
\hline
\end{tabular}

Source: IMF staff calculations.

1/ Dependent variable is the difference in the saving rate. The estimation uses annual data for the 1968-2005 period. Standard errors are in parentheses. *,**, and *** indicate significance at the 10 percent, 5 percent, and 1 percent levels, respectively.

Table 3. Australia: Time-Series Regression Results for Household Saving 1/

\begin{tabular}{lccccc}
\hline & \multicolumn{2}{c}{ HEW in Long and Short Run } & & \multicolumn{2}{c}{ HEW in Short Run Only } \\
\cline { 2 - 3 } & Coefficient & Standard error & & Coefficient & Standard error \\
\hline Long-run relationship & -0.05 & $(0.03)$ & $*$ & -0.07 & $(0.01)$ \\
Net worth & -0.44 & $(0.53)$ & & \\
HEW & 0.38 & $(0.29)$ & 0.38 & $(0.29)$ \\
Error-correction term & -0.20 & $(0.18)$ & -0.15 & $(0.18)$ \\
$\Delta$ (HEW) & & & & \\
\hline
\end{tabular}

Source: IMF staff calculations.

1/ Dependent variable is the difference in the saving rate. The estimation uses annual data for the 1979-2005 period. Standard errors are in parentheses. *,**, and *** indicate significance at the 10 percent, 5 percent, and 1 percent levels, respectively.

Table 4. United Kingdom: Time-Series Regression Results for Household Saving 1/

\begin{tabular}{|c|c|c|c|c|c|}
\hline & \multicolumn{2}{|c|}{ HEW in Long and Short Run } & \multicolumn{3}{|c|}{ HEW in Short Run Only } \\
\hline & $\overline{\text { Coefficient }}$ & Standard error & $\overline{\text { Coefficient }}$ & Standard error & \\
\hline Long-run relationshi] & & & & & \\
\hline Net worth & -0.02 & $(0.03)$ & -0.02 & $(0.04)$ & \\
\hline HEW & -0.18 & $(0.55)$ & & & \\
\hline Error-correction term & 0.32 & $(0.37)$ & 0.26 & $(0.30)$ & \\
\hline$\Delta(\mathrm{HEW})$ & -0.51 & $(0.28)$ & -0.47 & $(0.22)$ & $* *$ \\
\hline
\end{tabular}

Source: IMF staff calculations.

$1 /$ Dependent variable is the difference in the saving rate. The estimation uses annual data for the 1989-2005 period. Standard errors are in parentheses. *,**, and *** indicate significance at the 10 percent, 5 percent, and 1 percent levels, respectively. 
The results with respect to home equity withdrawal varied across countries. In the United Kingdom and Australia, HEW was not found significant in the long-run relationship. The short-run coefficient in the Australian regression is of a similar magnitude to the U.S. result, but is not significant, while in the United Kingdom the effect was close to a half, and statistically significant. The effect of HEW on saving was also less temporary in these regressions. Canada stands out as a special case, with an improbably large and positive coefficient in the long-run relationship and a small, statistically insignificant short-term coefficient. Given the small scale and limited fluctuations in HEW over time, we regard this result as most likely reflecting spurious correlations.

We ran a panel regression (Table 5), although in view of cross-country heterogeneity this exercise is mostly intended as an illustration and the summary of the data. The results support the conclusion that HEW matters for saving in the short run with an effect of around 20 cents on the dollar, but not in the long run. The negative long-run coefficient on net worth equals approximately three cents per dollar. The long-run coefficient on the nominal interest rate is about 0.9 (an increase in the nominal rate of one percentage point raises the saving rate in the long run by 0.9 percentage points). ${ }^{20}$

Table 5. Panel Regression Results for Household Saving 1/

\begin{tabular}{lccccccc}
\hline & \multicolumn{2}{c}{ HEW in Long and Short Run } & & \multicolumn{2}{c}{ HEW in Short Run Only } \\
\cline { 2 - 3 } & Coefficient & Standard error & & Coefficient & Standard error \\
\hline Long-run relationship & & & & & & \\
Net worth & -0.03 & $(0.02)$ & $*$ & & -0.03 & $(0.02)$ & $*$ \\
Nominal interest rate & 0.81 & $(0.32)$ & $* *$ & & 0.87 & $(0.36)$ & $* *$ \\
HEW & -0.36 & $(0.37)$ & & & 0.11 & $(0.05)$ & $* *$ \\
Error-correction term & 0.13 & $(0.05)$ & $* * *$ & -0.18 & $(0.09)$ & $* *$ \\
$\Delta$ (HEW) & -0.20 & $(0.09)$ & $* *$ & & &
\end{tabular}

Source: IMF staff calculations.

$1 /$ Dependent variable is the difference in the saving rate. The estimation is on an unbalanced panel of annual data with 132 observations and country fixed effects. Standard errors are in parentheses. ***, and *** indicate significance at the 10 percent, 5 percent, and 1 percent level, respectively.

\section{RECENT EXPERIENCE OF HEW IN AUSTRALIA AND UNITED KINGDOM: IMPLICATIONS FOR UNITED STATES?}

Given the concerns about the impact of the incipient slowdown in the growth rate of U.S. housing prices, it is instructive to examine the experiences of the countries that have recently gone through such a slowdown, namely Australia and the United Kingdom.

\footnotetext{
${ }^{20}$ Results are similar if the inflation rate is entered instead of the nominal interest rate. The real interest rate has not been found statistically significant in the panel regression.
} 
In all three countries, the link between real house prices and consumption appears to have weakened dramatically since 2000 (see Figure 8).

While there was some decline in HEW around the time of house price deceleration in Australia and United Kingdom, quarterly data suggest that the rebound in the saving rate was relatively small (Figure 9). ${ }^{21}$ This is broadly consistent with our regression results that imply changes in HEW have a limited, short-term effect on saving.
Figure 8. House Price Increases and Consumption Growth 1 I

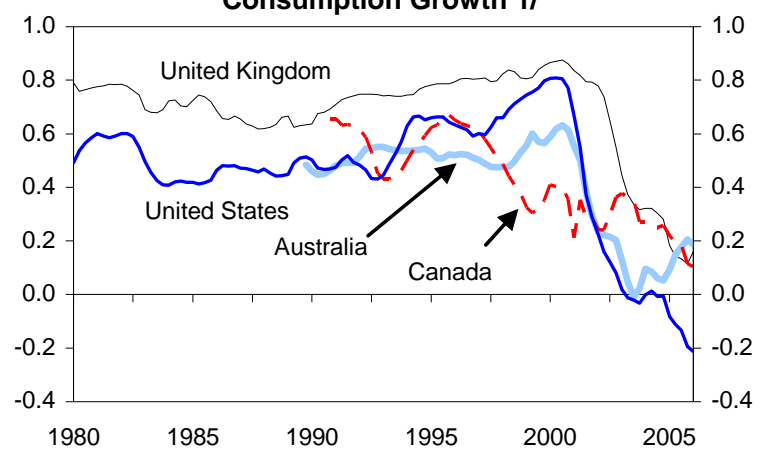

Sources: Haver Analytics; CEIC; National Sources; and IMF staff calculations.

1 / Ten-year rolling correlation between growth of real house price index (deflated by personal consumption deflator) and growth in private consumption.

Figure 9. Australia and United Kingdom: House Prices and Home Equity Withdrawal
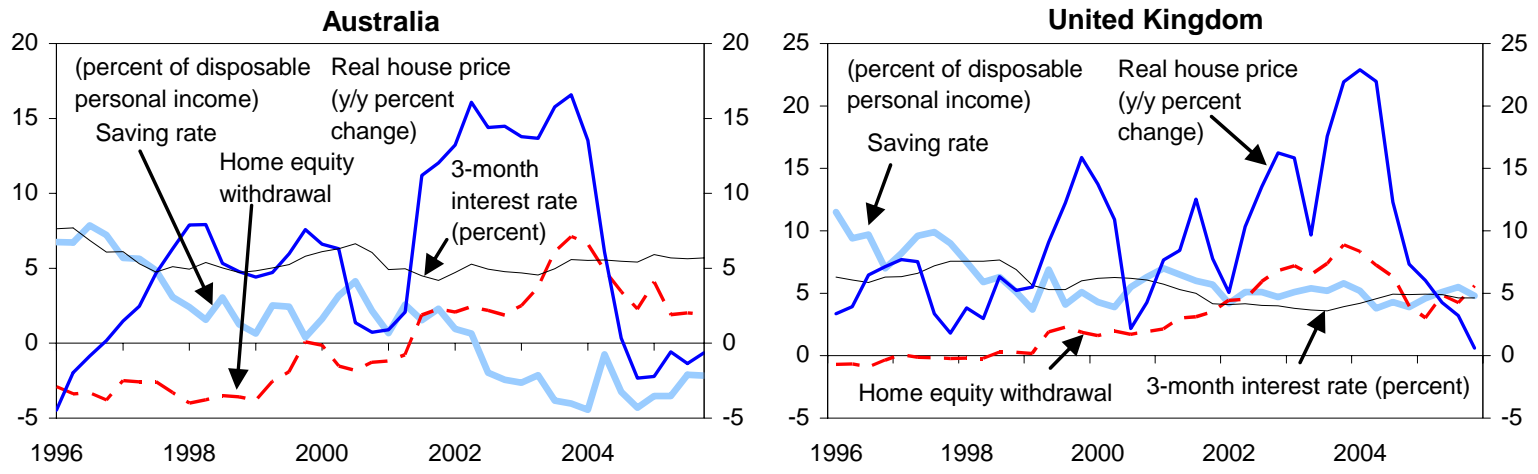

Sources: Haver Analytics; National Sources; and IMF staff calculations.

\section{CONCLUSIONS}

The regression results reported here are consistent with earlier studies in finding that U.S. households react to an increase in their net worth and lower real interest rates by reducing their saving rate. HEW also has a negative impact on household saving in the short run, although its size is limited. This result indicates that the likely slowdown in U.S. house price growth, HEW, and tightening financial conditions will lead to a recovery in the U.S. saving rate. However, this rise is likely to be limited - for example, even a reduction in the HEW ratio from the current 9 percent to its long-run average of 1 percent in a year would temporarily boost the saving rate by about $1 \frac{1}{4}$ percentage points, broadly consistent with the recent experience of Australia and the United Kingdom. That said, a decline in the growth of

${ }^{21}$ The HEW series used here are gross rather than net. 
HELs and cash-out refinancing may have at least as large an impact, and possibly a more persistent one, on housing investment through its effect on home improvement spending.

The inclusion of a trend variable, intended to represent the effects of financial liberalization and innovation, is strongly significant in the U.S. regression results (although not elsewhere). This is consistent with evidence that financial innovation lowers household saving by increasing access to financial products. Another implication of this trend is that households could be able to smooth consumption more effectively, lowering its volatility. 


\section{Financial Liberalization and Mortgage Product InNovation}

\section{A. Selected Measures of Financial Liberalization}

Australia Interest rate ceilings (1980) and other controls (1984) on bank deposits abolished. Limits on savings bank assets abolished (1982).

Entry of new banks permitted, including foreign banks; abolition of exchange controls (1983)

Securitization introduced (1987)

Canada Ceiling on bank loan interest rate abolished (1967)

Restrictions on bank mortgage financing abolished (1967)

Bank mortgage subsidiaries permitted (1980)

Securitization introduced (1987)

United Abolition of capital controls (1979), money supply and credit controls (1980) and

Kingdom minimum lending rate (1981)

Banks allowed to compete with building societies (1981)

Building societies allowed to diversify assets and funding sources (1986)

Securitization introduced (1987)

Second Banking Directive implemented (1993)

First issue of covered bonds (2003)

United Securitization introduced (1971)

States Phasing out deposit interest rate cap (Regulation Q - 1980 on)

Elimination of thrift portfolio restrictions (1980)

Sources: Boone et al. (2001); and Commonwealth Treasury of Australia.

\section{B. Recent Mortgage Product Innovations}

Australia Flexible mortgages with variable repayments;

Split-purpose loans (for primary and tax advantaged buy-to-let loans);

Deposit bonds (insurance company guarantees payment of deposit at settlement);

Nonconforming loans;

Redraw facilities and offset accounts;

New providers including mortgage originators and brokers.

Canada Shorter-term mortgages, initial fixed-rate period shortened from five years to one year, more variable rate loans;

Skip-a-payment, early mortgage renewal and flexible payment schedules.

Easier access to subprime loans.

United Flexible mortgages;

Kingdom Offset mortgages (savings and mortgage held in same/linked accounts, with savings offset against mortgage balance);

Base rate trackers.

Lifetime mortgages-equity release for retired homeowners

United Hybrid and Interest-only loans with variable rates;

States Flexible mortgages with variable repayment options, including negative amortization.

Sources: Scanlon and Whitehead (2004); and OECD (2005). 


\section{DATA Issues}

The personal saving rate in the U.S. National Income and Product Accounts (NIPA) is measured as a ratio of personal saving to personal disposable income. Both saving and income are net of consumption of fixed capital, which represents primarily the depreciation of housing stock. The personal sector includes households and nonprofit institutions serving households (NPISH). Separate accounts for the two subsectors are available for only a limited period for the United States and are not available for the other countries in this study. It should also be noted that households enter not only as consumers and providers of factors of production, but also as producers ("unincorporated businesses"-for example, family farms). While we are in principle interested only in the former role of the households, statistically separation between the two is infeasible, as, for example, the same assets may be used both for personal and business purposes.

The calculation of personal saving in the four countries in this study is fairly similar. The only exception is the United Kingdom, which focuses on gross rather than net saving. There are more differences in the definition of disposable income. In particular, while interest payments by households are subtracted before disposable income is calculated in Australia and the United Kingdom, so that personal saving equals personal disposable income minus personal consumption, in the United States and Canada some interest payments and some transfers are considered to be made out of disposable income. There are also some idiosyncrasies in the treatment of pension funds. Calculating saving rates on a uniform basis for the four countries would be quite a complicated enterprise, and would likely result in rather small and stable corrections. We have opted to use the national measures, which also have the advantage of being recognizable, except for the United Kingdom, where we subtract consumption of fixed capital from both saving and disposable income to arrive at the net ratio, comparable to that of the other three countries.

Home equity withdrawal is calculated as the difference between borrowing secured on dwelling and net acquisition of residential assets, both from the flow of funds. For Australia and the United Kingdom, residential investment (from national accounts) net of consumption of fixed capital is used as the subtrahend, since the flow of funds accounts cover only financial flows. For Australia, borrowing secured on dwelling was calculated from a scaled up series on the stock of housing debt for the household sector provided by the Reserve Bank of Australia.

Our measure of HEW for the United States is close to a widely cited estimate by Greenspan and Kennedy (2005), but is not identical due to differences in definition (in particular, Greenspan and Kennedy focus on discretionary equity withdrawal) and coverage. The Bank of England publishes regularly a measure of home equity withdrawal (Bank of England, 2006), and the Reserve Bank of Australia has shown its estimates on several occasions (Reserve Bank of Australia, 2003, 2005). The evolution of their measures over time is very close to that of our measures, but the level is lower largely because they arrive at their 
measures by subtracting gross rather than net housing investment from borrowing secured on housing.

Household net worth is calculated as a sum of the value of residential real estate and financial assets minus liabilities, from national balance sheets. The inflation rate is the year-on-year growth rate of the consumer price index, and the real interest rate is calculated as the nominal interest rate minus inflation. For the United States and Canada, the interest rate is the yield on a three-month treasury bill; for Australia, it is the 90-day bank acceptance rate; and for the United Kingdom, it is the 3-month London interbank offer rate (LIBOR). 


\section{References}

Bank for International Settlements (BIS), 2006, "Housing Finance in the Global Financial Market,” Committee for Global Financial Stability Papers No. 26, January (Basel).

Bank of England, 2006, Mortgage Equity Withdrawal: Q4 2005. Available on the Web at: http://www.bankofengland.co.uk/statistics/mew/2005.htm.

Benito, A., and J. Power, 2004, “Housing Equity and Consumption: Insights from the Survey of English Housing,” Bank of England Quarterly Bulletin (Autumn), pp. 302-09.

Bennett, P., R. Peach, and S. Persistani, 2001, "Structural Change in the Mortgage Market and the Propensity to Refinance," Journal of Money, Credit and Banking (November), pp. 955-76.

Boone, L., N. Girouard, and I. Wanner, 2001, “Financial Market Liberalization, Wealth and Consumption,” OECD Economics Department Working Paper No. 308 (Paris: Organization for Economic Cooperation and Development).

Canner, G., K. Dynan, and W. Passmore, 2002, "Mortgage Refinancing in 2001 and Early 2002,” Federal Reserve Bulletin (December), pp. 469-81.

Catte, P., N. Girouard, R. Price, and C. Andre, 2004, "Housing Markets, Wealth and the Business Cycle,” OECD Economics Department Working Paper No. 394, (Paris: Organization for Economic Cooperation and Development).

Council of Mortgage Lenders (CML), 2005, "UK Mortgage Funding,” Housing Finance, (February).

Frankel, A., 2006, "Prime or Not So Prime? An Exploration of US Housing Finance in the New Century,” BIS Quarterly Review, March, 67-78.

Galí, Jordi, 1990, “Finite Horizons, Life-Cycle Savings, and Time-Series Evidence on Consumption” Journal of Monetary Economics, Vol. 26, pp. 433-52.

Greenspan, A., and J. Kennedy, 2005, “Estimates of Home Mortgage Originations, Repayments, and Debt On One-to-Four-Family Residences,” Finance \& Economics Discussion Series, (Washington: Board of Governors of the Federal Reserve System) September.

Hicks, John R., 1939, Value and Capital (Oxford, United Kingdom: Oxford University Press).

JP Morgan, 2006, Skimming to Froth from the Punchbowl, Economic Research (New York). 
Jump, Gregory V., 1980, "Interest Rates, Inflation Expectations, and Spurious Elements in Measured Real Income and Saving,” American Economic Review, Vol. 70, No. 5, pp. 990-1004.

Krainer, J., and M. Marquis, 2003, “Mortgage Refinancing,” Federal Reserve Bank of San Francisco Economic Letter (October),

Maki, Dean M., and M.G. Palumbo, 2001, "Disentangling the Wealth Effect: A Cohort Analysis of Household Saving in the 1990s," Board of Governors of the Federal Reserve System, Finance and Economics Discussion Series (Washington).

McConnell, M., R. Peach, and A. Al-Haschimi, 2003, “After the Refinancing Boom: Will Consumers Scale Back Their Spending?” Current Issues in Economics and Finance, (Federal Reserve Bank of New York) (December) Vol. 9 No. 12.

Organization for Economic Cooperation and Development (OECD), 2005, "Recent House Price Developments: The Role of Fundamentals,” Economic Outlook, Vol. 78, (December).

Perozek, Maria G., and M.B. Reinsdorf, 2002, “Alternative Measures of Personal Saving,” Survey of Current Business, Vol. 82, No. 4, pp. 13-24.

Reinsdorf, Marshall B., 2004, “Alternative Measures of Personal Saving,” Survey of Current Business, Vol. 84, No. 9, pp. 17-27.

Reserve Bank of Australia (RBA), 2003, “Housing Equity Withdrawal,” Reserve Bank of Australia Bulletin (February).

_ Australia Bulletin (October).

Scanlon, K., and C. Whitehead, 2004, International Trends in Housing Tenure and Mortgage Finance (London: Council of Mortgage Lenders).

United Kingdom Financial Services Authority (FSA), 2006, Regulation of Home Reversion and Home Purchase Plans, CP 06/08, April.

van Els, P.J.A., W.A. van den End, and M.C.J. van Rooi, 2005, "Financial Behaviour of Dutch Households: Analysis of the DNB Household Survey 2003,” BIS Papers No. 22 (April), 21-39 (Basel: Bank for International Settlements). 